\title{
Tingkat Keberdayaan Kelompok Tani pada Pengelolaan Usahatani Padi di Daerah Istimewa Yogyakarta, Jawa Tengah
}

\section{The Empowerment Level of Farmer Groups on Rice Farming Management in Yogyakarta Province, Central Java}

\author{
Muhammad Nur Jaya ${ }^{1}$, Sarwititi Sarwoprasodjo², Musa Hubeis ${ }^{3}$, Basita Ginting Sugihen ${ }^{2}$ \\ ${ }^{1}$ Program Studi Komunikasi Pembangunan Pertanian dan Pedesaan ,Sekolah Pascasarjana, Institut Pertanian Bogor, Bogor \\ ${ }^{2}$ Departemen Sains Komunikasi dan Pengembangan Masyarakat, Fakultas Ekologi Manusia, Institut Pertanian Bogor, Bogor \\ ${ }^{3}$ Departemen Agribisnis, Fakultas Ekonomi dan Manajemen, Institut Pertanian Bogor, Bogor
}

\begin{abstract}
The empowerment level of farmer groups is the essential output of the empowerment process conducted through the implementation of participatory development communication in rice farming management. The aims of the study were to analyze the level of empowerment of rice farmer groups and to analyze the factors that affected the empowerment level of rice farmer groups. The research was conducted in Kulon Progo and Sleman district, involving 170 farmer groups as the analysis unit. The collected data were presented descriptively and explanatorily by SEM (Structural Equation Modeling) analysis. The results of the study shows that: (a) The rice farmer groups in general are less able to increase their empowerment level related to their farming activities; (b) The implementation of participatory development communication directly influences the empowerment level of farmer groups; (c) The utilization of social capital has an indirect effect on the empowerment level of farmer groups through the implementation of participatory development communication as a mediating variable.
\end{abstract}

Keywords: Empowerment, participatory development communication, social capital, farming, farmer groups

\begin{abstract}
Abstrak
Keberdayaan kelompok tani merupakan out put dari proses pemberdayaan yang dilakukan terhadap para pelaku usahatani padi, proses pemberdayaan dilakukan dengan melalui penerapan komunikasi pembangunan partisipatif pada pengelolaan usahatani padi. Penelitian ini bertujuan menganalisis tingkat keberdayaan kelompok tani padiserta menganalisis faktor yang berpengaruh terhadap tingkat keberdayaan kelompok tani padi.Penelitian ini menggunakan paradigma positivistik dengan menggunakan metode survey.Penelitian kuatitatif dilaksanakan di Kabupaten Kulon Progo dan Sleman dan yang menjadi obyek penelitian atau unit analisis adalah kelompok tani dengan mengambil sampel 170 kelompok tani. Data hasil penelitian dianalisis secara deskriptif dan eksplanatif dengan menggunakan SEM (Structural Equation Modeling) analisis. Hasil Penelitian adalah : (a) Kelompok tani secara keseluruhan kurang mampu meningkatkan keberdayaannya terkait usahatani padi ; (b) Pelaksanaan komunikasi pembangunan partisipatif berpengaruh langsung terhadap tingkat keberdayaan kelompok tani ; (c) Pemanfaatan modal sosial berpengaruh tidak langsung terhadap tingkat keberdayaan kelompoktanimelalui pelaksanaan komunikasi pembangunan partisipatif sebagai peubah mediasi.
\end{abstract}

Kata kunci : Keberdayaan, komunikasi pembangunan partisipatif, modal sosial, usahatani, kelompok tani

\section{Pendahuluan}

Pembangunan sektor pertanian di wilayah Indonesia, sejak orde baru sampai pascareformasi terus ditingkatkan pengelolaannya dengan berbagai caradilakukan baik oleh pemerintah, pihak terkait dan masyarakat tani sendiri. Peran pemerintah dalam hal pengembangan pembangunan pertanian ialah dengan memberikan program pemberdayaan masyarakat untuk mengurangi angka kemiskinan khususnya didaerah pedesaaan. Walaupun sampai saat ini masyarakat tani khususnya petani padi belum sepenuhnya berdaya secara ekonomi, sosial, politik dan lingkungan. Indikator kurangnya keberdayaan masyarakat ditunjukkan dalam(BPS 2014,2013,2015), memaparkan sebagai berikut: a). Ada sejumlah petani padi yang memiliki lahan $<0,5$ Ha yaitu sebanyak 83,11 $\%$ atau 73.680 petani mempunyai lahan sempit bahkan ada sebagai beruh tani; b) Petani dengan luas lahan $<$ 0,5 Hamemiliki pendapatan rata rata Rp. 2.849.000 pertahun; c). Ada 45.073 kepala keluarga atau 13,89 $\%$ tergolong miskin; d). Tingkat partisipasi masyarakat masih rendah.Pembanguan pertanian masih menemui berbagai kendala dalam pengelolaannya, sebab belum terintegrasi secara maksimal dengan sektor terkait dan belum didukung oleh sumber daya manusia dan sumber daya alam .

Bentuk-bentuk pemberdayaan masyarakat

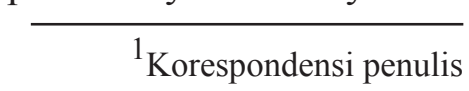

E-mail: nurjaya1962@yahoo.com 
tani padi di Kabupaten Sleman dan Kulon Progo menggunakan model program mandiri dan program pemerintah (SL-PTT sejak 2007sampai GP-PTT tahun 2015). Sejak era pemerintahan Susilo Bambang Yudhoyono dengan model revitalisasi pertanian berbagai program pengembangan pembangunan pertanian telah diluncurkan dengan tujuan program agar masyarakat tani mampu berdaya secara ekonomi, politik, sosial budaya dan lingkungan. Program SL-PTT (Sekolah Lapangan Pengelolaan Tanaman Terpadu) memberikan bantuan berupa benih unggul, saprodi, penerapan teknologi inovasi pertanian dan sekolah lapangan. Kelompok tani dan anggotanya melaksanakan program ini menggunakan sistim kawasan.Program SL-PTT memberikan pengetahuan usaha tani melalui sekolah lapangan bagi kelompok tani yang difasilitasi dengan laboratorium lapangan seluas $1 \mathrm{Ha}$ sawah dalam kawasan $25 \mathrm{Ha}$, menggunakan sistem pembelajaran praktek langsung dilapangan. Kelompok tani langsung berpartisipasi dalam kegiatan budidaya tanaman padi sebagai pilot proyek dalam meningkatkan keberdayaan kelompok tani. Kelompok tanimengikuti pelatihan yang berkaitan dengan usahatani, masyarakat turut serta dalam kegiatan pelatihan tersebut, agar pasca pelatihan para kelompok tani dapat mandiri dan mampu meningkatkan sendiri usahataninya serta dapat menyebarkan teknologi inovasi pertanian kepada kelompok tani sekitarnya (Direktorat Jenderal Tanaman Pangan, 2015).

Undang-Undang No. 16 tahun 2006 tentang Sistem Penyuluhan Pertanian, Perikanan, dan Kehutanan menjadi payung pelaksanaan programprogram peningkatan kualitas pemberdayaan SDM (Sumber Daya Manusia) dalam bidang pertanian, perikanan, dan kehutanan (Pemerintah R.I, 2006). Pada bidang pertanian pemberdayaan kelompok tani menjadi faktor kunci yang dibutuhkan agar petani mampu menjadi pelaku utama dalam pengelolaan sumberdaya pertanian.Pembangunan pertanian merupakan bagian dari upaya pemberdayaan kelompok tani dalam meningkatkan kemampuan melalui: pelatihan, penyebaran informasi, pendampingan, pengembangan sistim dan sarana pemasaran,konsolidasi dan jaminan luas lahan, kemudahan akses ilmu pengetahuan, teknologi informasi,serta penguatan kelembagaan (Pemerintah R.I, 2013).

Luaran dari kegiatan pemberdayaan adalah keberdayaan, olehnya itu untuk mencapai keberdayaan, pelaku usahatani harus melakukan sebuah proses. Salah satu proses yang dilalui adalah melakukan aktivitas komunikasi pada saat musyawarah dalam pengelolaan usahatani padi. Partisipasi kelompok tani dalam musyawarah, serta turut serta dalam pengambilan keputusan terkait dengan perencanaan, pelaksanaan, pengawasan dan evaluasi program pembangunan pertanian diharapkan dapat meningkat keberdayaannya. Untuk mendukung keberdayaan petani didukung oleh beberapa faktor seperti konsep (Servaes 2002), menyatakan proses komunikasi pembangunan partisipatif terkait konsep pemberdayaan diantaranya adanya forum dialog akar rumput, fungsi baru komunikasi, adanya media partisipatif, berbagi pengetahuan secara setara dan model komunikasi pendukung pembangunan. Konsep ini menjelaskan bahwa komunikasi pembangunan partisipatif dapat memengaruhi keberdayaan kelompok tani.

Masyarakat diajak merumuskan permasalahan dan menemukan pemecahannya sekaligus pelaksanaan kegiatan untuk pemecahan permasalahan.Oleh Schuler et al. (1996) menekankan aspek keberdayaan pada mobilitas dan pengambilan keputusan.(Besette, 1996; Mepolopolus, 2003) menekankan tujuan komunikasi pembangunan partisipatif adalah pengambilan keputusan.Msibi(2010)menekankantujuankomunikasi partisipatif adalah pemberdayaan masyarakat yaitu masyarakat turut serta dalam mengidentifikasi masalah pembangunan, mencari solusinya dan mengambil keputusan tentang masalah pembangunan pertanian. White (2004), menunjukan partisipasi adalah pengambilan tindakan dan menentukan arah perubahan sosial masyarakat.Tindakan dan arah perubahan dimaksudkan: kekuasaan, pengendalian, dialog, penyadaran, berbagi pengetahuan, pemberdayaan dan kesetaraan. Temuan Chitnis (2005) upaya yang dilakukan program CRHP (Comprehensive Rural Health Project) dalam memberdayakan perempuan miskin dibidang kesehatan, dengan berpartisipasi dalam pelatihan kesahatan. Luaran pemberdayan adalah masyarakat mampu mengakses informasi kesehatan dan memfasilitasi tindakan kolektif dalam pelaksanaan proyek kesehatan.

Asumsi pemanfaatan modal sosial di tingkat masyarakat dapat meningkatkan tingkat keberdayaan kelompok tani. Modal sosial merupakan energi yang tersimpan dalam masyarakat apabila digunakan secara efektif maka akan mampu meningkatkan kesejateraan masyarakat seperti dalam konsep (Putnam et al.1993), menyatakan ciri organisasi sosial, seperti trust, norma sosial dan jaringan sosial, dapat meningkatkan efisiensi masyarakat dan memfasilitasi koordinasi. Temuan Bhuiyan (2011), menyatakan modal sosial merupakan: sumber daya yang dapat digunakan,memfasilitasi 
interakasi sosial, mendukung adanya kerjasama, meningkatkan hasil aktivitas sosial politik, ekonomi dan mampu mengembangkan masyarakat yang lebih layak

Berdasarkan latarbelakang tersebut diatas maka berikut dirumuskan permasalahan yaitu sejauhmana tingkat keberdayaan kelompok tani padi serta faktor yang berpengaruh terhadaptingkat keberdayaan kelompok tani padi di Kabupaten Kulon Progo dan Sleman ?Tujuan penelitian adalah : 1. Menganalisis tingkat keberdayaan kelompok tani padi di Kabupaten Kulon Progo dan Sleman ; 2. Menganalisis faktor yang berpengaruh terhadap tingkat keberdayaan kelompok tani padi di Kabupaten Kulon Progo dan Sleman .

\section{Metode Penelitian}

Penelitian ini menggunakan paradigma positivistik dengan metodologi penelitian adalah kuantitatif, serta menggunakan motode survey. lokasi penelitian adalah Kabupaten Kulon Progo dan Kabupaten Sleman.Pemilihan lokasi tersebut karena dua lokasi dimaksud menyelenggarakan usahatani padi dengan program GP-PTT (Gerakan Penerapan Pengelolaan Tanaman Terpadu) padi.Peneliti menetapkan populasi dengan pendekatan kelompok yaitu kelompok tani yang berada di Kabupaten Sleman dan Kulon Progo dengan jumlah populasi sebanyak 268 kelompok tani.

Pada penelitian ini tidak semua populasi dapat dijadikan sebagai sumber informasi atau responden maka ditentukan besarnya sampeldengan menggunakan rumus Slovin (Kriyantono, 2006) sebagi berikut :

$$
\begin{array}{cl}
\mathrm{N} & \mathrm{e}=1 \% \text { sampai } 10 \% \\
\mathrm{n}=\mathrm{-} & \mathrm{N}=\text { jumlah populasi } \\
1+\mathrm{Ne}^{2} & \mathrm{n}=\text { jumlah sampel }
\end{array}
$$

Berdasarkan rumus penentuan besarnya sampel diatas dengan jumlah populasi sebesar 268 kelompok tani dengan mengambil tingkat kesalahan yang ditolerir sebesar $5 \%$ maka diperoleh jumlah sampel sebesar 170 kelompok tani .

Sampel penelitian adalah kelompok tani sebanyak 170 kelompok tani, sehingga yang menjadi responden adalah anggota kelompok yang merepresentasikan kelompok tani. Kelompok tani terdiri atas pengurus dan anggota kelompok maka peneliti memilih tiga anggota kelompok mewakili kelompok sebagai responden. Responden yang dipilih adalah 1 pengurus dan 2 anggota aktif dengan dipilih secara random.

Pengambilan sampel dengan menggunakan Cluster sampling (areal sampling). Untuk tingkat kabupaten besarnya sampel ditentukan secara proporsional sehingga diperoleh: Kabupaten Sleman sebesar 115/268 x 170=73 kelompok sedangkan untuk Kabupaten Kulon Progo sebesar 153/268 x $170=97$ kelompok. Pada penelitian ini menggunakan instrumen berupa daftar pertanyaan terstruktur didasarkan pada indikator yang digunakan. Data yang digunakan adalah data ordinal, rasio dan interval, kemudian data dianalisis secara deskriptif daneksplanatif dengan menggunakan SEM (Structural Equation Modeling ) analisis.

\section{Hasil dan Pembahasan}

\section{Tingkat Keberdayaan Kelompok Tani}

Kajian keberdayaan kelompok tani padi dalam penilitian ini merupakan hasil dari tujuan pelaksanaan komunikasi pembangunan partisipatif yaitu tindakan pengambilan keputusan terkait usahatani.Keberdayaan yang hendak dicapai oleh kelompok tani dalam hal ini adalah keberdayaan dari sisi luaran komunikasi berupa tindakan yang akan dilakukan oleh kelompok tani. Berkaitan dengan prinsip dasar dari tujuan komunikasi maka keberdayaan yang diukur dalam penelitian ini adalah : Kemampuan kelompok tani dalam mengelola informasi pertanian yang diterima, kemampuan kelompok tani dalam mengambil keputusan terkait usahatani padi, kemampuan kelompok tani dalam manejerial usahatani padi, kemampuan kelompok tani dalam memasarkan hasil produksi usahatani dan kemampuan kelompok tani dalam menerapkan teknologi inovasi pertanian atau penerapan teknik budi daya padi. Elemen yang direfleksikan dalam keberdayaan ini adalah berhubungan dengan pengambilan keputusan oleh kelompok tani terkait aktivitas usahatani yang akan dilakukan.

Konsep keberdayaan diatas sejalan dengan temuan Schuler at al. (1996) keberdayaan ditekankan pada tingkat mobilitas, keberdayaan dilihat dari sisi kebebasan dalam pengambilan keputusan, dan peluang untuk ikut dalam kegiatan politik. Konsep Malhotra 
Tabel 1. Sebaran Responden berdasarkan Peubah Tingkat Keberdayaan Kelompok Tani

\begin{tabular}{llcrrr}
\hline \multirow{2}{*}{ Peubah } & Pengukuran & $\begin{array}{c}\text { Kulon Progo } \\
(\mathbf{\%})\end{array}$ & $\begin{array}{c}\text { Sleman } \\
(\mathbf{\%})\end{array}$ & $\begin{array}{c}\text { Kabupat- } \\
\text { en total }\end{array}$ & Sig (Uji t) $^{\mathbf{1}}$ \\
\hline Tingkat keberdayaan kelompok tani & Sangat Rendah & 0.00 & 0.00 & 0.00 & \\
& Rendah & 74.23 & 61.64 & 68.82 & \\
& Tinggi & 22.68 & 35.62 & 28.24 & \\
& Sangat tinggi & 3.09 & 2.74 & 2.94 & \\
\hline Rataan & Skor & 46.51 & 43.81 & 45.16 & 0.070 \\
\hline
\end{tabular}

Keterangan : $\quad \mathrm{n}$ Kulon Progo $=97$, Sleman $=73$, Total $=170$

1) Rataan skor indeks; sangat rendah $=0-25$, rendah $=26-50$, tinggi $=51-75$, sangat tinggi $=76-100$;

$\left.{ }^{2}\right)$ *nyata pada $\mathrm{p}<0.05$ dan $* *$ sangat nyata pada $\mathrm{p}<0.01$

at al. (2002), menyatakan keberdayaan diukur dari sisi ekonomi, sosial budaya, keluarga, hukum, politik dan psikologis.Utama (2010), mengukur keberdayaan diantaranya kapasitas mengambil tindakan dan kemampuan kolektif.Sadono (2012), mengukur keberdayaan diantaranya kemampuan mengambil keputusan dan kemampuan mengakses pasar.

Sebaran responden berdasarkan beberapa indikator yang direfleksikan pada tingkat keberdayaan kelompok tani tersaji pada tabel 1 dan tabel 2

Hasil penelitian menunjukkan bahwa tingkat keberdayaan kelompok tani secara keseluruhan berada pada kategori rendah. Rendahnya tingkat keberdayaan kelompok tani disebabkan beberapa hal : kelompok tanikurang mampu mengelola informasi pertanianyang diterima melalui media cetak, elektronik, media interpersonal dan media, untuk didistribusikan kepada kelompok tani lain; kelompok tani kurang mampu memanejerial usahataninya sebelum pelaksanaan budi daya padi; kelompok tani kurang mampu memasarkan hasil usahatani. Di sisi lain tingkat keberdayaan berada pada kategori tinggi yaitu:kelompok tani mampu mengambil keputusan secara bersama dan independen dalam musyawarah kelompok terkait pengelolaan usahatani padi, dan kelompok tani mampu melakukan teknologi inovasi pertanian atau teknik budi daya padi.

\section{Kemampuan Mengelola Informasi Pertanian}

Hasil analisis penelitian tertera pada Tabel 2, sebaran responden dari indikator kemampuan mengelola informasi berada pada kategori rendah dengan rataan 43,52 , ada 65,88 persen kelompok tani kurang mampu mengelola informasi, ada 4,71 persen kelompok tani tidak mampu mengelola informasi, selebihnya kelompok tani mampu dan sangat mampu mengelola informasi pertanian yang diterima. Sebagian besar kelompok tani yang berada di Kabupaten Kulon Progo dan Sleman kurang mampu mengelolah informasi pertanian yang diterima.Kurang sejalan temuan Mulyandari (2011), menyatakan petani di Jawa Barat dan Jawa Timur mempunyai kemampuan mengelola informasi pertanian yang diterima dengan kategori sedang.

Pekerjaan mengelola informasi terdiri dari mencari informasi,mendapatkan, memproduksinya dan memanfaatkannya untuk diri sendiri serta mendistribusikankan kepada kelompok tani lain. Menurut Rogers (2003), menggambarkan proses mencari informasi untuk mendapatkan dan menggunakan terdiri dari beberapa tahap yakni tahap pengetahuan, persuasi, mengambil keputusan, implementasi, dan tahap konfirmasi. Rogers (1981) informasi dicari dan didapatkan kemudian didistribusikan kepada pihak lain disini terjadi proses berbagi informasi kemudian dikelola dan selanjutnya dimanfaatkan secara bersama setelah mencapai kesepahaman bersama.

Konsep tersebut diatas, terkait pekerjaaan mengelola informasi adalah pekerjaan yang harus ditunjang oleh tingkat pengetahuan yang dimiliki dan tingkat keterampilan dalam mendistribusikan informasi kepada pihak lain. Rata-rata kelompok tani yang memperoleh informasi dari pihak mana saja hanya didengar dan dilihat begitu saja tidak didiskusikan dengan pihak lain. Olehnya itu mengapa kelompok 
Tabel 2. Sebaran, Rataan, dan Hasil Uji Beda Responden berdasarkan Indikator Tingkat Keberdayaan Kelompok Tani

\begin{tabular}{|c|c|c|c|c|c|}
\hline Peubah & Pengukuran & $\begin{array}{c}\text { Kulon } \\
\text { Progo } \\
\text { (\%) }\end{array}$ & $\begin{array}{c}\text { Sleman } \\
(\%)\end{array}$ & $\begin{array}{c}\text { Kabupaten } \\
\text { total }\end{array}$ & $\underset{(\mathbf{U j i} \mathbf{t})^{1}}{\text { Sig }}$ \\
\hline \multirow[t]{4}{*}{ Kemampuan mengelola informasi pertanian } & Tidak mampu & 4.12 & 5.48 & 4.71 & \\
\hline & Kurang mampu & 59.79 & 73.97 & 65.88 & \\
\hline & Mampu & 35.05 & 20.55 & 28.82 & \\
\hline & Sangat mampu & 1.03 & 0.00 & 0.59 & \\
\hline Rataan & Skor & 45.15 & 41.88 & 43.52 & 0.082 \\
\hline \multirow[t]{4}{*}{ Kemampuan mengambil keputusan bersama } & Tidak mampu & 5.15 & 4.11 & 4.71 & \\
\hline & Kurang mampu & 28.87 & 42.47 & 34.71 & \\
\hline & Mampu & 59.79 & 45.21 & 53.53 & \\
\hline & Sangat mampu & 6.19 & 8.22 & 7.06 & \\
\hline Rataan & Skor & 60.21 & 58.22 & 59.21 & 0.382 \\
\hline \multirow[t]{4}{*}{ Kemampuan manajemen usahatani } & Tidak mampu & 5.15 & 5.48 & 5.29 & \\
\hline & Kurang mampu & 53.61 & 68.49 & 60.00 & \\
\hline & Mampu & 31.96 & 21.92 & 27.65 & \\
\hline & Sangat mampu & 9.28 & 4.11 & 7.06 & \\
\hline Rataan & Skor & 43.40 & 41.16 & 42.28 & 0.305 \\
\hline \multirow[t]{4}{*}{ Kemampuan memasarkan hasil usaha } & Tidak mampu & 2.06 & 4.11 & 2.94 & \\
\hline & Kurang mampu & 68.04 & 73.97 & 70.59 & \\
\hline & Mampu & 25.77 & 16.44 & 21.76 & \\
\hline & Sangat mampu & 4.12 & 5.48 & 4.71 & \\
\hline Rataan & Skor & 41.46 & 39.66 & 40.56 & 0.366 \\
\hline \multirow[t]{4}{*}{ Kemampuan penerapan teknologi inovasi } & Tidak mampu & 4.12 & 8.22 & 5.88 & \\
\hline & Kurang mampu & 19.59 & 35.62 & 26.47 & \\
\hline & Mampu & 70.10 & 47.95 & 60.59 & \\
\hline & Sangat mampu & 6.19 & 8.22 & 7.06 & \\
\hline Rataan & Skor & 62.31 & 58.13 & 60.22 & 0.057 \\
\hline
\end{tabular}

Keterangan: $\quad \mathrm{n}$ Kulon Progo $=97$, Sleman $=73$, Total $=170$

1) Rataan skor indeks ; sangat rendah $=0-25$, rendah $=26-50$, tinggi $=51-75$, sangat tinggi $=76-100$;

$\left.{ }^{2}\right)$ *nyata pada $\mathrm{p}<0.05$ dan ** sangat nyata pada $\mathrm{p}<0.01$.

tani kurang mampu bahkan tidak mampu mengelola informasi yang diterima, sebab sebagian besar kelompok tani tingkat pendidikannya rendah yaitu hanya setingkat SMP. Selain itu kelompok tani juga kurang antusias dalam mencari informasi pertanian atau tingkat kosmopolitannya rendah berdasarkan hasil penelitian ini. Apabila kelompok tani kurang mampu mendapatkan informasi maka akibatnya akan memengaruhi kemampuan dalam mengelola informasi pertanian untuk didistribusikan kepada kelompok tani lain dan untuk diri sendiri.

\section{Kemampuan Mengambil Keputusan Bersama}

Hasil analisis penelitian tertera pada Tabel.2, sebaran responden dari indikator kemampuan mengambil keputusan berada pada kategori tinggi dengan rataan 59,21. Ada 53,53 persen kelompok 
tani mampu mengambil kepetusan bersama terkait usahatani dan 7,06 persen kelompok tani sangat mampu mengambil keputusan bersama selebihnya adalah petani kurang mampu dan tidak mampu mengambil keputusan bersama. Pengambilan keputusan oleh kelompok tani terkait usahatani menyangkut pemilihan dan penentuan bibit unggul, penentuan sistim tanam jajar logowo (4:1,2:1,3:1), penentuan pemupukan berimbang (pupuk organik dan non organik), pengairan berselang, cara pengendalian hama dan pelaksanaan pasca panen. Sebagian besar kelompok tani memeliki kemandirian atau independensi dalam pengambilan keputusan, sebab kelompok tani adalah kelompok tani yang memiliki, atau menyewa, atau menggarap lahan sendiri bukan sebagai buru. Kelompok tani memiliki kepentingan sebagai pemilik/penggarap/penyewa untuk meningkatkan produktivitas usahataninya, sehingga kebanyakan kelompok tani berani mengambil keputusan bersama dan mandiri.Terkait pengambilan keputusan bersama ada kaitannya dengan penguasaan lahan menurut (Sajogyo, 1985) peluang berusaha tani oleh petani sangat ditentukan oleh penguasaan lahan.Oleh Sumardjo (1999) memaknai penguasaan adalah petani berhak mengambil keputusan atas usaha pertanian terkait dengan lahan yang dikuasai baik sebagai penggarap, pemilik dan penyewa.

Menurut Rahmat (2008) ada beberapa faktor personal yang memengaruhi pengambilan keputusan yaitu pengetahuan, motif dan dan sikap.Terkait kemampuan mengambil keputusan berketegori tinggi sebab petani memiliki motif yang kuat tentang keberhasilan usaha tani, olehnya itu kelompok tani berani mengambil keputusan karena menyangkut keberhasilan usahanya.Faktor motif berhubungan dengan pengusaan lahan oleh patani baik sebagai pemilik, penyewa dan pengagarap seperti dikonsepkan oleh (Sajogyo 1985 dan Sumarjo 1999).

Sebagian kecil kelompok tani kurang mampu mengambil keputusan terkait usahatani padi bahkan ada yang tidak mampu mengambil keputusan, sebab kelompok tani tersebut kurang mau mengambil risiko, apabila keputusan yang diambil kurang tepat. Terkait usahatani di lokasi penelitianpemerintah meluncurkan program GP-PTT (Gerakan Penerapan Pengelolaan Tanaman Terpadu) padi. Pada program tersebut sudah ditentukan teknologi inovasi yang akan diterapkan dalam pengelolaan usahatani padi, kelompok tani tinggal menjalankan program tersebut sesuai petunjuk teknis. Kelompok tani kesulitan untuk mengambil keputusan terkait masalah usahatani,sebab pengambilan keputusan sesengguhnya merupak pilihan dari alternatif solusi yang ada. Program yang diluncurkan telah direncanakan dari atas, maka program tersebut memiliki design (ketentuan program telah tersedia), masyarakat sebagai penerima bantuan tinggal melaksanakan saja.

\section{Kemampuan Manajemen Usahatani}

Hasil analisis penelitian tertera pada Tabel 2, sebaran responden dari indikator kemampuan manajemen usahatani berada pada kategori rendah dengan rataan 42,28. Ada 60 persen kelompok tani kurang mampu memanajemeni usaha tani dan 5,29 persen kelompok tani tidak mampu memanajemeni selebihnya adalah petani yang mampu dan sangat mampu memanajemeni usahatani sekitar 34 persen. Sejalan temuan Aminah (2013), menyatakan kemampuan manajerial petani dalam merencanakan dan mengevaluasi usahatani di Kabupaten Halmahera Barat berada pada kategori rendah.

Kelompok tani kurang mampu memanajemeni usahatani yaitu kurang mampu merencanakan usahatani sebelum pelaksanaan, kurang mampu mengorganisir pelaksanaan usahatani, kurang mampu mengawasi dan mengevaluasi pelaksanaan usahatani padi.Pekerjaan terkait manajemen sebagian besar kelompok tani kesulitan dalam melakukannya, sebab kurang pengetahuan dan keterampilan.Selain itu kelompok tani kurang mampu memanejemini usahataninya, sebab sebagian besar kelompok tani memiliki luas lahan garapan sangat sempit sehingga petani tidak punya kesempatan dan kemauan untuk melakukan manejemen usahatani terlebih dahulu sebelum pelaksanaan fisik usahatani.Kelompok tani banyak melakukan pekerjaan lain, selain bertani untuk menambah penghasilannya sehingga tidak punya waktu dan pengetahuan untuk melakukan manajemen usahatani padi.

Temuan tentang kurang mampumemanejemeni usahatani kurang sejalan dengan konsep Shinta A (2011), yang menggambarkan pengelolaan usahatani adalah kemampuan petani dalam merencanakan, mengorganisir, mengarahkan, mengkoordinasikan dan mengawasi faktor produksi yang dimiliknya. Kurang sejalan konsep George RT (1987), yang menyatakan manajemen merupakan suatu proses yang terdiri dari planning, organizing, actuating dan controlling 
untuk mencapai tujuan dengan menggunakan manusia dan sumber daya lainnya. Menurut konsep James (1981),menggambarkanmanajemen sebagai proses perencanaan, pengorganisasian, pengarahan dan pengawasan usaha organisasi dan penggunaan sumber daya organisasi lainnya agar mencapai tujuan organisasi yang telah ditetapkan.

Hasil penelitian menenjukkan bahwa kelompok tani kurang mampu bahkan tidak mampu memanajemeni usaha taninya dengan baik.Apabila manajemen yang dimaksud sesuai konsep manajemen tersebut diatas oleh beberapa ilmuan dan peneliti, maka untuk mampu melakukan pekerjaan menyangkut manajemen yang direfleksikan diatas tidak mudah dilakukan.Kelompok tani membutuhkan pengetahuan, pendidikan dan keterampilan yang cukup.Hambatan tingkat pengetahuan, pendidikan dan keterampilan didukung oleh hasil pengamatan terhadap kelompok tani, bahwa sebagian besar kelompok tani didua lokasi penelitian tingkat pendidikannya rendah yaitu setingkat SMP dan SD sekitar 60 persen. Kelompok tani tidak melakukan manajemen karena kemampuannya terbatas dan membutuhkan waktu dan keterampilan tersendiri. Hal lain yang mendukung adalah kelompok tani kurang berpartisipasi dalam pelaksanaan komunikasi pembangunan partisipatif di tingkat musyawarah membahas usahatani padi. Pada hal tujuan dari proses komunikasi adalah upaya untuk meningkatkan keberdayaan kelompok tani dan pelaksanaan komunikasi partisipatif merupakan bagian dari upaya pemberdayaan kelompok tani/masyarakat tani (Msibi 2010; White 2004 ;Servaes 2002).

\section{Kemampuan Memasarkan Hasil Usahatani}

Hasil analisis penelitian tertera pada Tabel 2.sebaran responden dari indikator kemampuan memasarkan hasil usahatani berada pada kategori rendah dengan rataan 40,56. Ada 70,59 persen kelompok tani kurang mampu dan 2,94 persen petani tidak mampu selebihnya adalah petani yang mampu dan sangat mampu memasarkan hasil usahanya sekitar 25 persen. Kategori rendah dalam memasarkan hasil usahatani dimaknai bahwa kelompok tani kurang mampu menjual hasil panen padinya dengan harga bersaing, kelompok tani kurang mampu mendapatkan informasi harga pasar, kelompok tani kurang mampu mendapatkan peluang pasar.

Temuan diatas kurang sejalan konsep Kotler dan Armstrong (2001), menyatakan konsep inti pemasaran adalah : kebutuhan ,keinginan, permintaan, produksi dan pelayanan, nilai kepuasan dan kualitas, pertukaran, transaksi, hubungan pemasaran, dan pasar. Menurut konsep Kotler tersebut dimaknai bahwa memasarkan hasil usaha tani adalah aktivitas yang terkait dengan memasarkan hasil usaha dengan harga yang bersaing, mampu mendapatkan informasi harga pasar, dan mampu mengakses peluang pasar.Kurang sejalan temuan Mulyandari (2011), petani di Batu memiliki jaringan pemasaran usahatani yang lebih luas, juga memiliki posisi tawar yang lebih baik dan lebih mudah mengakses harga pasar.

Hasil temuan penelitian sebagian besar kurang mampu memasarkan hasil usahataninya, karena petani selalu menjual hasil usaha tanaman padi dalam bentuk padi dan gabah basah di sawah oleh pedagang atau penebas yang memang datang langsung ke sawah pada saat musim panen.Sebagian besar petani tidak memeliki waktu untuk melakukan pengolahan padi menjadi beras.selain itu untuk mengelola padi menjadi beras membutuhkan waktu yang panjang dan modal untuk pengolahan pada hal kebanyakan petani secepatnya membutuhkan modal untuk melakukan penanaman padi berikutnya. Akhirnya kebanyakan kelompok tani segera menjualnya dalam bentuk padi dan gabah basah di sawah kepada penebas.

Antara petani dengan pedagang/penebas melakukan negosiasi ditempat, sehingga rata rata petani kurang memiliki kemampuan dari posisi penawaran harga yang bersaing. Kelompok tani biasanya kurang memperhatikan proses negosiasi harga yang penting bagi petani gabahnya cepat terjual untuk memenuhi kebutuhannya. Petani tidak perlu lagi membawah gabahnya kepasar yang tentunya membutuhkan biaya transportasi, hal ini sering dilakukan petani karena menurut sebagian petani lebih menguntungkan dari pada susah mencari pasar ditempat lain.

Terkait mengakses informasi pasar hasil penelitian memperlihatkan bahwa kelompok tani kurang mampu mengakses informasi pasar hal ini didukung dengan hasil penelitian ini yaitu tingkat kosmopolitan kelompok tani, ditemukan kelompok tani kurang kosmopolit.Kelompok tani kurang antusias dalam mencari informasi terkait usaha tani. Ada korelasi antara kemampuan mengakses informasi pasar dan tingkat kosmopolitan petani, petani kurang mampu mengkases informasi pasar bisa disebabkan oleh salah satunya kurang memiliki kemauan untuk 
mencari informasi atau kosmopolitannya kurang.

\section{Kemampuan Penerapan Teknologi Inovasi Pertanian}

Hasil analisis penelitian tertera pada Tabel 2.sebaran responden dari indikator kemampuan penerapan teknologi inovasi berada pada kategori tinggi dengan rataan 60,22. Ada 60,59 persen kelompok tani mampu menerapkan teknologi inovasi pertanian dan 7,06 persen petani sangat mampu, selebihnya adalah petani kurang mampu dan tidak mampu menerapkan teknologi inovasi pertanian.Sejalan temuan Muchtar (2015), kemampuan penerapan teknologi inovasi oleh petani di Desa Abbokongeng sangat tinggi. Kurang sejalan temuan Aminah (2013), kemampuan petani tentang teknik budi daya rendah, petani kurang mampu dalam melakukan pemupukan, pengendalian hama dan pasca panen.

Teknologi inovasi usaha tani yang direfleksikan dalam pengukuran instrument adalah pengolahan tanah, pemilihan bibit unggul, penentuan sistim tanam jajar logowo $(4: 1,3: 1,2: 1)$, pemupukan berimbang, pengairan berselang, pemberantasan hama dan pelaksanaan paska panen. Temuan dilapangan menunjukkan bahwa sebagian besar kelompok tani lebih mampu menerapkan teknologi inovasi pertanian di dua lokasi penelitian, sebab rata rata petani tersebut telah mengikuti program SL-PTT (Sekolah Lapangan Pengelolaan Tanaman Terpadu) sejak tahun 2007 sampai program GP-PTT 2015. Kedua program pemerintah tersebut menerapkan teknologi inovasi budi daya tanaman padi yang sama, jadi pada dasarnya kelompok tani lebih mengenal dan mengetahui teknologi tersebut. Juga indikator keberhasilan GPPTT dapat dilihat dari peningkatan pengetahuan, keterampilan dan perubahan sikap, penerapan budidaya usahatani padi yang baik dan benar, peningkatan produktivitas dan keberlanjutan serta replikasinya.Hal ini sejalan dengan temuan dalam penelitian ini terkait instrument kebaruan informasi pertanian, berada pada kategori rendah artinya informasi yang diterima bukan lagi informasi baru diperoleh tapi sudah beberapa kali diperoleh dari program pemerintah sejak tahun 2007.

Hasil temuan tersebut terkait bahwa informasi teknologi inovasi pertanian terkait pemilihan dan penentuan bibit unggul, sistim tanam jajar logowo, pemupukan berimbang dan pengendalian hama sudah berkali kali disosialisasikan kepada kelompok tani. Kelompok tani secara otomatis akan meningkat pengetahuannya tentang teknologi tersebut, sehingga efek perilakunya adalah mampu mengerjakan teknologi inovasi pertanian. Kelompok tani mampu melaksanakan penanaman padi sistim tanam jajar logowo, mampu melakukan pemupukan secara berimbang.Apalagi program pemerintah SL-PTT (Sekolag Lapangan Pengelolaan Tanaman Terpadu) dan GP-PTT (Gerakan Penerapan Pengelolaan Tanaman Terpadu) menerapkan prinsip partisipatif termasuk model komunikasi pembangunan partisipatif. Sedangkan efek komunikasi pembangunan partisipatif adalah perilaku atau tindakan, tindakan yang dimaksudkan mampu menerapkan teknik budi daya padi dengan teknologi inovasi pertanian.

\section{Faktor yang Memengaruhi Tingkat Keberdayaan Kelompok Tani}

Hasil analisis dengan metode SEM(Structural Equation Modeling) menggunakan software LISREL 8.70.(Wijayanto 2008).Hasil uji kesesuaian model menunjukkan bahwa hybrid model yang diperoleh seperti Gambar 1.Model yang dihasilkan sudah good fit karena telah memenuhi kriteria seperti terlihat pada Tabel 3.Model yang dihasilkan melalui penelitian dapat diberlakukan untuk populasi yang digunakan yaitu kelompok tani di Kabupaten Kulon progo dan Sleman. Hasil analisis menghasilkan model struktural dalam bentuk diagram lintasan sebagaimana yang disajikan pada Gambar 1.

Berdasarkan kerangka pikir tingkat keberdayaan petani dipengaruhi oleh dua peubah yaitu pelaksanaan komunikasi pembangunan partisipatif dan pemanfaatan modal sosial. Setelah dilakukan analisis SEM (Structural Equation Modeling) diperoleh bahwa peubah pemanfaatan modal sosial tidak mempunyai pengaruh yang signifikan sehingga jalur itu dikeluarkan dari model. Tingkat keberdayaan petani secara langsung dipengaruhi oleh peubah tunggal pelaksanaan komunikasi pembangunan partisipatif $\left(\mathrm{Y}_{1}\right)$ nilai pengaruhnya sebesar 0,82 atau 67,24 persen. Secara simultan pengaruh peubah pelaksanaan komunikasi pembangunan partisipatif terhadap keberdayaan petani sebesar 0,66 hal ini mempunyai makna bahwa keragaman data yang bisa dijelaskan oleh model tersebut sebesar 66 persen sedangkan sisanya dijelaskan oleh peubah lain yang belum terdapat dalam model. Model persamaan struktural 


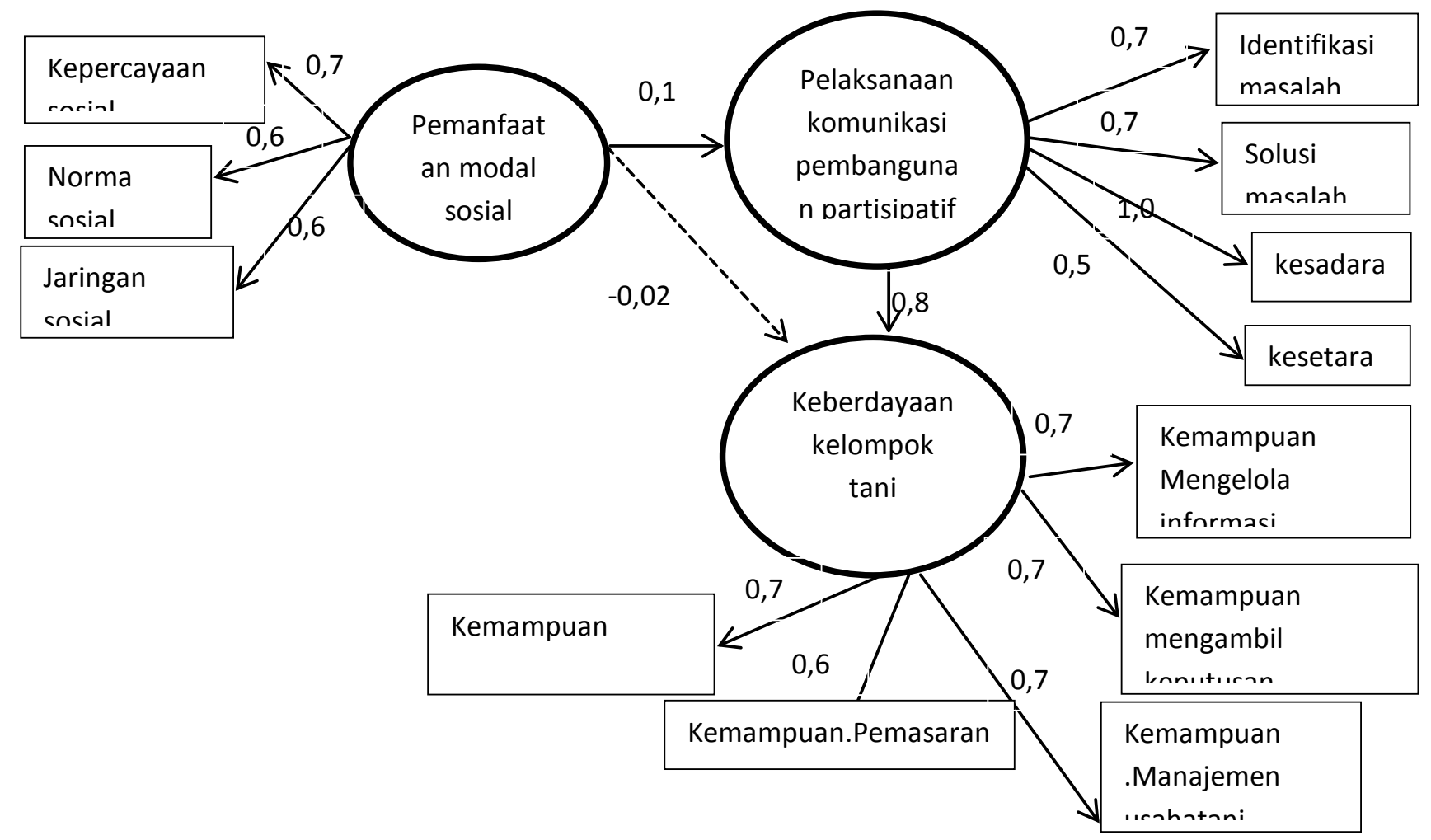

Gambar 1. Model Struktural dan Faktor Modal Sosial dan Pelaksanaan Komunikasi Pembangunan Partisipatif Memengaruhi Keberdayaan Kelompok Tani

faktor yang memengaruhi keberdayaan kelompok tani padi adalah:

$\mathrm{Y}_{2}=0,82 * \mathrm{Y}_{1}-0,018 \mathrm{X}_{5}, \mathrm{R}^{2}=0,66 \ldots \ldots($ persamaan 1$)$

Untuk menguji hipotesis dilakukan dengan membandingkan nilai t-hitung dan $\mathrm{t}$ tabel untuk masing-masing peubah. Jika nilai t-hitung masingmasing peubah lebih besar dari t-tabel $(1,96)$ pada taraf nyata 0,05 , maka hipotesis diterima. Mengacu pada persamaan 1, Gambar 1.dan Tabel 4 maka secara statistik pelaksanaan komunikasi pembangunan partisipatif, berpengaruh nyata terhadap tingkat keberdayaan kelompok tani besarnya pengaruh tersebut sebesar 0,82 atau 67,24 persen, sedangkan modal sosial tidak mempunyai pengaruh karena tidak signifikan. Hipotesis penelitian "Pelaksanaan komunikasi pembangunan partisipatif dan modal sosial memengaruhi tingkat keberdayaan petani“. Hipotesis ini tidak semuanya diterima hanya satu peubah yang terbukti mempunyai pengaruh langsung terhadap tingkat keberdayaan kelompok tani yaitu peubah komunikasi pembangunan partisipatif $\left(\mathrm{Y}_{1}\right)$. Jadi hipotesis untuk peubah pelaksanaan komunikasi pembangunan partisipatif $\left(\mathrm{Y}_{1}\right)$ diterima, sedangkan peubah pemanfaatan modal sosial ditolak. Dari persamaan 1 diatas terlihat sebagai berikut : Koefisien lintas pelaksanaan komunikasi pembangunan partisipatif $\left(\mathrm{Y}_{1}\right)$ adalah 0,82 hal ini berarti besarnya pengaruh pelaksanaan komunikasi pembangunan partisipatif $\left(\mathrm{Y}_{1}\right)$ terhadap keberdayaan petani $\left(\mathrm{Y}_{2}\right)$ adalah $0,82^{2}=67,24$ persen. Pengaruh peubah pelaksanaan komunikasi pembangunan partisipatif terhadap tingkat keberdayaan kelompok tani serta pengaruh tidak langsung peubah pemanfaatan modal sosial terhadap keberdayaan kelompok tani yang dimediasi oleh pelaksanaan komunikasi pembangunan partsisipatif diuraikan sebagai berikut :

\section{Pelaksanaan Komunikasi Pembangunan Partisipatif}

Pelaksanaan komunikasi pembangunan partisipatif memengaruhi secara langsung dan positif terhadap keberdayan kelompok tani. Mempunyai makna semakin tinggi partisipasi kelompok tani dalam pelaksanaan komunikasi pembangunan partisipatif akan meningkatkan keberdayaan kelompok tani. Sebaliknya semakin rendah partisipasi kelompok tani dalam pelaksanaan komunikasi pembangunan partisipatif akan menjadi rendah tingkat keberdayaan kelompok tani.Pelaksanaan komunikasi pembangunan partisipatif saat berlangsungnya musyawarah, digambarkan kelompok tani melakukan aktivitas komunikasi model partisipatif berupa: a). Kelompok 
Tabel 3. Pengujian Goodness of Fit Model

\begin{tabular}{lrrl}
\hline $\begin{array}{c}\text { Goodness-of- } \\
\text { Fit }\end{array}$ & $\begin{array}{c}\text { Cutt-off- } \\
\text { Value }\end{array}$ & Hasil & Kesimpulan \\
\hline $\begin{array}{l}\text { Chi square } \\
(p \text {-value })\end{array}$ & & 0.000 & Tidak good fit \\
RMSEA & 0.08 & 0.070 & good fit \\
GFI & $\geq 0.90$ & 0.910 & good fit \\
CFI & $\geq 0.90$ & 0.910 & good fit \\
IFI & $\geq 0.90$ & 0.910 & good fit \\
\hline
\end{tabular}

Ket: pengaruh langsung modal sosial terhadap keberdayaan kelompok tani tidak signifikan $-0,02$

tani mengajukan pertanyaan, pendapat, saran, sanggahan dan bantahan menyangkut pengolahan tanah, pemilihan dan penentuan bibit unggul, sistim tanam jajar logowo, teknik pemupukan berimbang, teknik pengaturan air, teknik pemberantasan hama dan pelaksanaan pasca panen;b). Kelompok tani melakukan dialog tentang solusi masalah pengolahan tanah, pemilihan dan penentuan bibit unggul, penentuan sistim tanam jajar logowo, pengaturan air, pemupukan berimbang, pemberantasan hama dan pelaksanaan pasca panen;c). Kelompok tani menyadari akan permasalahan pengolahan tanah, pemilihan bibit, pengaturan air, pemupukan berimbang, pemberantasan hama dan pelaksanaan pasca panen dan permasalahan lain diluar teknologi budi daya berupa pemilikan lahan sempit, akses permodalan, sehingga perlu untuk dikomunikasikan dengan kelompok tani lainnya saat musyawarah; d). Kelompok tani melakukan dialog secara setara tentang pengelolaan usaha tani, kelompok tani mendapat kesempatan seluas-luasnya untuk mengutarakan aspirasinya dan pendapatnya dalam upaya meningkatkan produktivitas usahatani. Partisipasi aktif kelompok tani dalam pelaksanaan komunikasipembangunan partisipatif saat musyawarah akan berpotensi meningkatkan keberdayaan kelompok tani.

Temuan tersebut sejalan temuan Mepolopolus (2003), praktek komunikasi partisipatif model dua arah memiliki potensi untuk mensupport, serta praktek komunikasi pembangunan partisipatif mempunyai kemampuan untuk menentukan kebutuhan masyarakat dan membantu keberdayaan. Sejalan temuan Msibi (2010)menyatakan proses komunikasi partisipatif untuk mengidentifikasi masalah dan membuat keputusan,memberdayakan masyarakat lokal Kungwini. Temuan Schuler et al. (1996) menekankan keberdayaan pada tingkat mobilitas, kebebasan dalam pengambilan keputusan, dan peluang untuk ikut dalam kegiatan politik. Sejalan temuan Chitnis (2005),melalui upaya komunikasi dilakukan oleh program CRHP (Comprehensive Rural Health Project) dalam memberdayakan perempuan miskin di bidang kesehatan, dengan berpartisipasi aktif dalam pelatihan kesehatan. luaran pemberdayaan adalah masyarakat mampu mengakses informasi kesehatan dan memfasilitasi tindakan kolektif dalam pelaksanaan proyek kesehatan. sebagai program dalam memberdayakan perempuandesa untuk pelayanan kesehatan dan perempuan desa menjadi VHWs (Village Health Workers). Searah temuan Wiyati (2014), akitivitas komunikasi kelompok berpengaruh nyata terhadap keberdayaan kelompok miskin di Sulawesi Tengah.

Pengelolaan usahatani merupakan bagian dari upaya pemberdayaan kelompok tani. Luaran pemberdayaan adalah keberdayaan, yang dimaksudkan dalam penelitian ini adalah kemampuan kelompok tani dalam mengelola informasi pertanian, kemampuan mengambil keputusan terkait usahatani, kemampuan memanajemni usahatani, kemampuan memasarkan hasil usahatani dan kemampuan melakukan teknologi inovasi atau teknik budi daya padi. Salah satu upaya pemberdayaan adalah melalui pelibatan kelompok tani dalam pelaksanaan komunikasi pembangunan

Tabel 4. Hasil Estimasi Model SEM

\begin{tabular}{lccccl}
\hline Pengaruh Variabel & Pengaruh langsung & $\begin{array}{c}\text { Pengaruh tidak } \\
\text { langsung }\end{array}$ & $\mathbf{R}^{\mathbf{2}}$ & $\mid \mathbf{t}$-hit $\mid>\mathbf{1 . 9 6}$ & Kesimpulan \\
\hline $\mathrm{X} 5 \rightarrow$ Y1 & 0.14 & & 2.75 & Signifikan \\
$\mathrm{X} 5 \rightarrow$ Y2 & -0.02 & 0,12 & & 0.30 & Tidak Signifikan \\
$\mathrm{X} 5 \rightarrow$ Y2 & & & 0,66 & 7.76 & Signifikan \\
Y1 $\rightarrow$ Y2 & 0.82 & & & \\
\hline
\end{tabular}

Keterangan: signifikan jika nilai $\mid$ t-hit $\mid>1.96$ 
Tabel 5. Sebaran, Rataan, dan Hasil Uji Beda Responden berdasarkan Indikator Pelaksanaan Komunikasi Pembangunan Partisipatif

\begin{tabular}{|c|c|c|c|c|c|}
\hline Peubah & Pengukuran & $\begin{array}{c}\text { Kulon Progo } \\
\text { (\%) }\end{array}$ & Sleman $(\%)$ & $\begin{array}{c}\text { Kabupaten total } \\
(\%)\end{array}$ & Sig $\left(U_{j} \mathbf{j i}\right)^{1}$ \\
\hline \multirow[t]{4}{*}{ Tahap Identifikasi masalah } & Sangat rendah & 2.06 & 1.37 & 1.76 & \\
\hline & Rendah & 37.11 & 42.47 & 39.41 & \\
\hline & Tinggi & 60.82 & 53.42 & 57.65 & \\
\hline & Sangat tinggi & 0.00 & 2.74 & 1.18 & \\
\hline Rataan & Skor & 50.41 & 52.07 & 51.24 & 0.294 \\
\hline \multirow[t]{4}{*}{ Tahap Solusi masalah } & Sangat rendah & 1.03 & 4.11 & 2.35 & \\
\hline & Rendah & 64.95 & 58.90 & 62.35 & \\
\hline & Tinggi & 31.96 & 34.25 & 32.94 & \\
\hline & Sangat tinggi & 2.06 & 2.74 & 2.35 & \\
\hline Rataan & Skor & 47.33 & 47.32 & 47.32 & 0.996 \\
\hline \multirow[t]{4}{*}{ Kesadaran diri } & Sangat rendah & 3.09 & 4.11 & 3.53 & \\
\hline & Rendah & 62.89 & 67.12 & 64.71 & \\
\hline & Tinggi & 30.93 & 21.92 & 27.06 & \\
\hline & Sangat tinggi & 3.09 & 6.85 & 4.71 & \\
\hline Rataan & Skor & 44.51 & 42.40 & 43.45 & 0.359 \\
\hline \multirow[t]{4}{*}{ Kesetaraan } & Sangat rendah & 0.00 & 2.06 & 1.18 & \\
\hline & Rendah & 64.38 & 42.27 & 51.76 & \\
\hline & Tinggi & 35.62 & 50.52 & 44.12 & \\
\hline & Sangat tinggi & 0.00 & 5.15 & 2.94 & \\
\hline Rataan & Skor & 44.11 & 51.52 & 47.81 & $0.002^{* *}$ \\
\hline
\end{tabular}

Keterangan : $\mathrm{n}$ Kulon Progo $=97$, Sleman $=73$, Total $=170$

1) Rataan skor indeks; sangat rendah $=0-25$, rendah $=26-50$, tinggi $=51-75$, sangat tinggi $=76-100$;

$\left.{ }^{2}\right)$ *nyata pada $\mathrm{p}<0.05$ dan $* *$ sangat nyata pada $\mathrm{p}<0.01$.

partisipati dalam musyawarah kelompok. Aktivitas komunikasi antara pelaku usahatani membuahkan hasil berupa keberdayaan yang dialami kelompok tani, sebab ini menyangkut efek komunikasi pembangunan partisipatif yaitu tindakan dalam pengambilan keputusan. Temuan ini sejalan temuan Jalieli (2013), tingkat partisipasi petani dalam perencanaan program pertanian (berdiskusi dan menyampaikan pendapat) berhubungan nyata dengan tingkat keberdayaan petani di Kabupaten Cirebon. Searah temuan Naido (2010), melalui komunikasi partisipatif lembaga GCIS (Goverment Communication Information Service) memastikan bahwa masyarakat berpartisipasi aktif dalam perencanaan, pengambilan keputusan dan kepemilikan proyek pembangunan. Sejalan temuan Schiller dan Wet (2016),peran dan fungsi komunikasi di pengasuhan yang memberdayakan semua peran pengurus,fungsionaris dan stokeholder.

Aspek tahapan kesadaran paling kuat merefleksikan pelaksanaan komunikasi pembangunan partisipatif menyusul aspek identifikasi masalah, solusi masalah dan kesetaraan dengan koefisien masing-masing $\lambda=1.00,0.78,0.76,0.53$ memengaruhi tingkat keberdayaan kelompok tani. Hasil penelitian terlihat pada Tabel 4. tahap identifikasi berada pada kategori tinggi artinya sebagian besar kelompok tani aktif mengajukan saran, pendapat, sanggahan dan bantahan terkait identifikasi masalah usahatani dalam musyawarah kelompok, akan meningkatkan tingkat keberdayaan kelompok tani. Mengapa kelompok tani berpartisipasi dalam pelaksanaan komunikasi pembangunan partisipatif pada tahap identifikasi 
masalah, sebab kelompok tani antusias memperhatikan program GP-PTT yang akan memberikan program pertanian dengan teknologi inovasi partanian. Program tersebut muncul berbagai permasalahan pertanian yang perlu dimusyawarakan untuk pengambilan keputusan dalam rangka peningkatan produktivitas sesuai sasaran program GP-PTT.

Hasil penelitian terlihat pada Tabel 5 aspek tahapan solusi masalah, kesadaran dan tahap kesetaraan berada pada kategori rendah berarti aspek tersebut dapat menyebabkan rendahnya tingkat keberdayaan kelompok tani. Rendahnya aspek tahapan solusi masalah menunjukkan kelompok tani kurang mengajukan pertanyaan, saran, pendapat, sanggahan dan bantahan tentang solusi masalah pengelohan tanah, pemilihan dan penentuan bibit unggul, penentuan sistim tanam jajar logowo, pemumpukan berimbang, pemberantasan hama dan pelaksanaan pasca panen serta solusi masalah kepemilikan lahan sempit dan akses permodalan. Temuan ini sejalan temuan Fitriyanti (2013), tahap pengambilan keputusan rendah, partisipasi petani rendah karena kurangnya keterlibatan masyarakat dalam memberikan masukan, ide dan kritik dalam proses pengambilan keputuan. Masalah kurangnya partisipasi kelompok tani dalam pelaksanaan komunikasi partisipatif terkait solusi masalah, sebab kelompok tani harus menerima apa yang diberikan oleh program tersebut. Program GP-PTT itu adalah program pemerintah yang telah direncanakan sebelum pelaksanaan sehingga teknologi inovasi pertanian sedah ditentukan dari perencanaan tersebut. Jadi kelompok tani tinggal melaksanakan saja sesuai hasil perencanaan program yang diluncurkan.

Rendahnya aspek kesadaran menunjukkan kelompok tani kurang menyadiri tentang pentingnya masalah usaha tani dikomunikasikan kepada pihak terkait dalam proses musyawarah untuk mencarikan solusinya. Hal ini menyangkut masalah pengolahan tanah, pemilihan dan penentuan bibit unggul yang sesuai lokasi dan keadaan tanah, pengaturan air irigasi yang kurang terpenuhi, pemupukan berimbang antara pupuk organik dan non organik, pemberantasan hama dan pelaksanaan pasca panen yang menyebabkan kehilangan produktivitas. Hal yang membuat kelompok tani kurang manyadari hal tersebut disebabkan sebagian besar kelompok tani lahan garapan yang dimiliki sempit ditambah kurang dapat mengakses permodalan sehingga petani kurang respek dengan pekerjaan pengelolaan usahatani.

Aspek tahapan kesadaran paling kuat merefleksikan pelaksanaan komunikasi pembangunan partisipatif dalam memberi pengaruh terhadap tingkat keberdayaan kelompok tani dengan nilai koefisien 1,00. Artinya kelompok tani menyadari akan pentingnya permasalahanusahatanimenyangkut pengolahan tanah, pemelihan bibit unggul, penentuan sistim tanam jajar logowo, pemupukan berimbang, pengairang berselang dan pasca panen untuk dikomunikasikan dalam musyawarah kelompok tani. Dengan terjadinya proses dialog antara kelompok tani akibat adanya kesadaran tersebut maka akan meningkatkan tingkat keberdayaan kelompok tani dari sisi pengelolaan usahatani padi. Temuan ini sejalan dengan konsep Freire (Pretty et.al 1995), yang memaknai partisipasi sebagai aksi kolektif dan dialog terbuka untuk meningkatkan kesadaran diri dan keyakinan dalam memberdayakan masyarakat yang terpinggirkan dan miskin.

Rendahnya kesetaraan menunjukkan kelompok tani kurang mendapat kesempatan seluas-luasnya dan kebebasan dalam berdialog atau mengajukan saran,pendapat, sanggahan dan bantahan tentang pengembangan usahatani dalam musyawarah kelompok. Hal ini masih terjadi,sebab lingkungan masyarakat tani masih ada hirarki kekuasaan belum sepenuhnya hilang. Ada sebagian kelompok tani menyatakan bahwa mereka sebagai anggota biasa atau masyarakat biasa lebih cenderung untuk menurut saja apa kehendak kelompok tani. Temuan ini sejalan dengan temuan Chitnis (2005) menjelaskan bahwa kesetaraan sangat terkait dengan kekuasaan artinya dalam masyarakat selalu terjadi dominasi oleh masyarakat yang memiliki kekuasaan walaupun sesungguhnya ada kesetaraan dalam aktivitas pembangunan. Temuan ini dipertegas oleh temuan Herman (2011) staff dari proyek donor kurang memberi kesempatan yang cukup kepada masyarakat lokal dalam berdialog tentang perencanaan proyek karena proyek sudah didesign dari atas. Hal ini terkait adanya ketidak setaraan antara pemberi bantuan dengan penerima bantuan.Jika aspek tahapan solusi masalah, kesadaran dan kesetaraan ditingkatkan perannya dalam proses komunikasi pembangunan partisipatif maka akan berpotensi untuk meningkatkan tingkat keberdayaan kelompok tani.

\section{Pemanfaatan Modal Sosial}

Hasil analisis SEM (Structural Equation Modeling) menghasilkan bahwa peubah pemanfaatan modal sosial mempunyai koefisien pengaruh sebesar $-0,02$ dengan $t$ hitung sebesar 0,3. Berdasarkan ketentuan bahwa t hitung lebih kecil dari t tabel $(1,96)$, maka pengaruhnya tidak signifikan. selain itu koefisien 
pengaruh lebih kecil dari 0,05 maka jalur antara peubah modal sosial dengan keberdayaan kelompok tani dihilangkan seperti terlihat pada Gambar 1. Namun disisi lain ditemukan bahwa pemanfaatan modal sosial mempunyai pengaruh tidak langsung sebesar 0,12 atau 1,44 persen terhadap tingkat keberdayaan kelompok tani. Pengaruh tidak langsung tersebut dengan t-hitung sebesar 2,39 artinya t-hitung lebih besar dari t-tabel sehingga keofisien pengaruh tersebut signifikan. Pengaruh tidak langsung lebih besar dari pengaruh langsung dimana pengaruh langsung lebih kecil dari 0,05 sehingga pengaruh tersebut dihilangkan.

Metode analisis multilevel pemanfaatan modal sosial mempunyai pengaruh tidak langsung terhadap tingkat keberdayaan kelompok tani melalui peubah mediasi pelaksanaan komunikasi pembangunan partisipatif. Artinya dengan meningkatkan peubah pemanfaatan modal sosial akan meningkatkan tingkat keberdayaan kelompok tani dengan terlebih dahulu dilakukan komunikasi yang partisipatif atau dialog dengan kelompok tani tentang pemanfaatan modal sosial dalam pengelolaan usahatani.Peubah komunikasi pembangunan partisipatif salah satu upaya pemberdayaan kelompok tani seperti ditegaskan oleh Servaes (2002), komunikasi pembangunan partisipatif terkait konsep pemberdayaan, adanya forum dialog akar rumput, fungsi baru komunikasi, media partisipatif, berbagi pengetahuan secara setara, dan model komunikasi pendukung pembangunan. Dialog akar rumput didasarkan kaidah partisipasi untuk mempertemukan sumber dan agen perubahan langsung dengan masyarakat.

Aspek kepercayaan sosial yang merefleksikan modal sosial memiliki pengaruh terhadap komunikasi pembangunan partisipatif.Melalui proses komunikasi yang partisipatif aspek saling percaya antar kelompok semakin kuat sehingga mampu meningkatkan tingkat keberdayaan kelompok tani.Kelompok tani mempercayai kelompok tani lain yang menyampaikan informasi usahatani padi terkait pengolahan tanah, pemilihan bibit, sistim tanam jajar logowo, pemupukan berimbang, pengairan berselang dan paska panen, dengan kepercayaan tersebut yang terlebih dahulu dikomunikasikan akan meningkatkan keberdayaan kelompok tani.

Aspek norma sosial yang merefleksikan modal sosial merupakan energi sosial yang kuat memengaruhi keberdayaan kelompok tani dengan terlebih dahulu di komunikasikan kepada kelompok tani. Norma sosial menyangkut aturan yang disepakati bersama dan biasanya warisan dari terdahulu seperti gotong royong, sopan santun, kerja sama dan wiwitan, aturan ini dibuat untuk mengatur kehidupan sosial masyarakat. Jika norma tersebut di komunikasi terlebih dahulu akan meningkatkan tingkat ketaatan kelompok tani terhadap norma dan tentunya akan meningkatkan pula tingkat keberdayaan kelompok tani. Tingkat keberdayaan kelompok tani menyangkut keberdayan dari sisi ekonomi, keberdayaan dalam pengambilan keputusan terkait pengelolaan usahatani.

Aspek Jaringan sosial yang merefleksikan modal sosial memiliki energi yang kuat jika jaringan sosial ini ditunjang dengan aktivitas komunikasi yang partisipatif antara kelompok tani. Kuatnya jaringan sosial akan meningkatkan tingkat keberdayaan kelompok tani dari sisi kemampuan melakukan kerja sama antara kelompok tani. Jaringan sosial berupa melakukan hubungan sosial dengan penyuluh, peneliti, petani sukses, tokoh masyarakat,dan organisasi tani dalam upaya melakukan kerja sama terkait usahatani. Hubungan sosial ini semakin meningkat apabila terlebih dahulu dilakukan proses komunikasi antara kelompok tani dan secara langsung akan meningkatkan keberdayaan kelompok tani dari sisi membangun kerja sama.

\section{Kesimpulan}

Tingkat keberdayaan kelompok tani berada pada kategori rendah secara keseluruhan. Artinya kelompok tani kurang mampu mengelola informasi pertanian yang diterima untuk keperluan usahatani, kurang mampu memanajemeni usahataninya, kurang mampu memasarkan hasil usahataninya. Di sisi yang lain kelompok tani mampu mengambil keputusan secara bersama dan mandiri terkait usahatani dan mampu melakukan teknologi inovasi pertanian atau teknik budi daya usahatani padi.

Tingkat keberdayaan kelompok tani dalam pengelolaan usaha tani dipengaruhi secara langsung dan positifoleh pelaksanaan komunikasi pembangunan partisipatif dengan tingkat pengaruh sebesar 0,82 atau 67,24 persen. Hal ini dimaknai bahwa semakin partisipatif dalam melakukan komunikasi pada saat musyawarah semakin meningkatkan keberdayaan kelompok tani sebaliknya kurang partisipatif dalam melakukan komunikasi maka tingkat keberdayaan kelompok tani menjadi rendah. Tingkat keberdayaan kelompok tani dalam pengelolaan usaha tani dipengaruhi secara tidak langsung dan signifikan oleh pemanfaatan modal sosial melalui peubah pelaksanaan komunikasi pembangunan partisipatif sebagai peubah 
mediasi.

\section{Daftar Pustaka}

Aminah S. 2013. Model Komunikasi Partisipatif untuk Keberdayaan Patani Kecil dalam Mewujudkan Ketahanan Pangan di Kabupaten Halmahera Barat. [disertasi]. Bogor (ID): Institut Pertanian Bogor.

Badan Pusat Statistik 2013. Potret Usaha Pertanian Kulon Progo Menurut Subsektor (Hasil Pencacahan Lengkap Sensus Pertanian 2013 dan Survei Pendapatan Rumah Tangga Usaha Pertanian 2013 ). Kulon Progo (ID): Badan Pusat statistik

Badan Pusat Statistik. 2014. Kulon Progo dalam Angka. Kulon Progo (ID): Badan Pusat Statistik. [internet]. [dapat diunduh dari http://kulonprogokab.bps. go.id

Badan Pusat Statistik. 2013. Potret Usaha Pertanian Sleman Menurut Subsektor (Hasil Pencacahan Lengkap Sensus Pertanian 2013 dan Survei Pendapatan Rumah Tangga Usaha Pertanian 2013 ). Sleman (ID): Badan Pusat statistik

Badan Pusat Statistik Kabupaten Sleman 2015. Sleman dalam Angka. Sleman (ID): Badan Pusat Statistk. [Internet].[dapat diunduh dari http://slemankab. bps.go.id

Bessette G, Rajasunderam CV.1996. Participatory Development Communication A.West African Agenda. Penang:International Development Research Centre.

Bhuiyan SH. 2011. Social Capital and Community Development: An Analysis of Two Cases from Indiaand Bangladesh.Journal of Asian and African Studies.46 (6): 533-545.

Chitnis KS. 2005. Communication for Empowerment and Participatory Development: A Social Model ofHealth in Jamkhed, India.[disertasi]. Athens:The Faculty the college of Communication of Ohio University

Direktorat Jenderal Tanaman Pangan. 2015. Pedoman Teknis GP-PTT padi. Jakarta (ID). Kementerian Pertanian Direktorat Jenderal Tanaman Pangan.

Fitriyanti N, Sadono D. 2013. Partisipasi Masyarakat dalam Program Nasional Pemberdayaan Masyarakat -Mandari di Desa Kotabatu Kecamatan Ciomas Kabupaten Bogor. Jurnal Penyuluhan. 9(1):80-87

George R.T 1977, Principles of Management, Richard O irwin. Inc. Home Wood. Illinois.

Hermann B. 2011.Crucial factors in the implementation ofparticipatory development communicationin Papua New Guinea. Contemporary PNG Studies Research Journal .15:115. DWU

Jalieli A, Sadono D. 2013. Tingkat Partisipasi dan Keberdayaan Petani Alumni Program SL-PTT (Kasus Desa Gegesik Wetan Kabupaten Cirebon. Jurnal Penyuluhan 9(2):99-108

James AF, Stoner. 1981. Manajemen. New York: Prentice Hall International. Inc Englewood Cliffs.

Kementerian Pertanian. 2013. Keputusan Direktur Jenderal Tanamana Pangan Nomor : 6/ HK.310/C/1/2013. Tentang Pedoman Teknis Sekolah lapangan Pengelolaan Tanaman Terpadu (SL-PTT) Padi dan Jagung. Jakarta (ID). Direktur Jenderal Tanaman Pangan.

Kotler, P and Armstrong, G, 2001, Principles of marketing (9 Edition). New Jersey. Prentice-Hall, inc

Kriyantono R. 2006. Teknik Praktis Riset Komunikasi. Jakarta (ID): Pranada Media Group.

Malhotra A,Schuler SR. 2002. Measuring Women's empowerment as a variable in International Development.the Gender and Development Group of the World Bank

Mefalopulos P. 2003. Theory and Practice of Participatory Communication:The case of the FAO Project "Communication for Developmentin Southern Africa. [disertasi]. The University of Texas at Austin.

Msibi F and Penzhorn C. 2010. Participatory communication for local government in South Africa: a study of the Kungwini Local Municipality . Information Devolepment journal international . 26 (3): 225-236.

Muchtar K, Susanto D dan Purnaningsih. 2015. Adopsi Teknologi Petani pada Sekolah Lapangan Pengelolaan Tanaman Terpadu (SL-PTT). Jurnal Penyuluhan 11(2):176-185

Mulyandari RSH. 2011. Cyber Extension Sebagai Media Komunikasi dalam Pemberdayaan Petani Sayur. [disertasi]. Bogor (ID): Institut Pertanian Bogor

Naidoo L. 2010. Participatory Development Communication Approach of Thusong Service Centres in Tshwane.[disertasi]. South Africa: Nort-West University.

Pemerintah Republik Indonesia. 2013. Undang Undang Republik Indonesia Nomor 19 tahun 2013, tentang Perlindungan dan Pemberdayaan Petani. Jakarta(ID): Pemerintah Republik Indonesia. [internet].[dapat diunduh dari http:// perundangan. 
pertanian.go.id]

Presiden Republik Indonesia 2006. Undang Undang

Republik Indonesia Nomor 16 tahun 2006 tentang Sistem Penyuluhan, Pertanian, Perikanan dan Kehutanan. Jakarta (ID) Presiden Republik Indonesia.[internet].[http://luk.staff.ugm.ac.id/ atur/horti/UU16-sistem penyuluhan ]

Pretty J, Guijt I, Scoones I and Thompson J. 1995. Participatory Learning and Action. A Trainer's Guide for Participatory Learning and Action. London: The International Institut for Environment and Develompment.

Putnam R, Leonardi R, Nanetti R. 1993. MakingDemocracy Work: CivicTraditions inModern Italy, Princeton.University Press.

Rahmat J. 2008. Psikologi Komunikasi. Bandung (ID): Pt.Remaja Rosdakarya.

Rogers, EM. 2003. Diffusion of Innovations. New York (NY):The Free Pres,

Rogers EM, Kincaid DL. 1981. Communication Network Towarda New Paradigm for Research. New York (NY): Free Press A Division of Macmillan Publishing Co.Inc.

Sajogyo P. 1985. Sosiologi Pembangunan . Jakarta (ID):Fakultas pasca sarjana IKIP Jakarta .

Sadono D. 2012. Model Pemberdayaan Petani dalam Pengelolaan Usahatani Padi di Kabupaten Karawang dan Cianjur Provinsi Jawa Barat. [disertasi]. Bogor (ID): Institut Pertanian Bogor.

Schuler SR, Hashemi SM, Riley AP, and Akhter S.1996. Credit Programs, patriarchi, and Men's Violence Against Women in rural Bangladesh. Social Science and Medicine. 43 (12): 635 - 653.

Schiller U, Wet GD. 2016, communication indegeneus culture and participatory decision making amongst foster adolescents. Qualitative social work 0 (00) $1-16$.

Servaes. 2002. Communication for Development one world Multiple Cultural. The United States of America (USA): Hampton Press.

Shinta A. 2011. Ilmu Usaha tani. Surabaya (ID): Universitas Brawijaya Press

Sumardjo. 1999. Transformasi model penyuluhan pertanian menuju pengembangan kemandirian petani [disertasi]. Bogor (ID): Institut Pertanian Bogor.

Utama S. 2010. Pemberdayaan masyarakat sekitar hutan melalui pendekatan kelompok. [disertasi]. Bogor (ID): Institut Pertanian Bogor.

White SA, Nair KS, and Ascroft J. 2004. Participatory
Communication Working For Change and Development. New Delhi. Sage Publication.

Wijayanto SH. 2008. Structural Equation Modelling dengan Lasrel 8.8. Yogyakarta (ID): PT.Graha Ilmu.

Wiyati EK. 2014. Pengaruh Aktivitas Komunikasi Kelompok terhadap Keberdayaan Kelompok Miskin di Sulawesi Tengah.[disertasi]. Bogor (ID): Institut Pertanian Bogor 